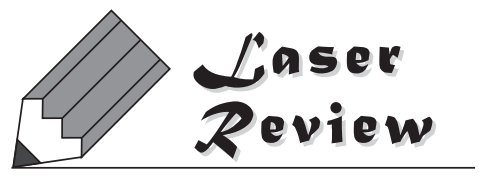

\title{
原子炉の保守保全に役立つレーザー技術
}

\author{
西村 昭彦 \\ 日本原子力研究開発機構（广619-0215 京都府木津川梅美台8-1-7 関西光科学研究所）
}

\section{Laser Technologies for The Nuclear Power Plant Maintenance}

\author{
Akihiko NISHIMURA \\ Japan Atomic Energy Agency, 8-1-7 Umebidai, Kizugawa-shi, Kyoto 619-0215
}

(Received November 2, 2011)

\begin{abstract}
The recent improvement of laser technologies will contribute to the maintenance of nuclear power plants. The Japan Atomic Energy Agency developed a specially designed probing system was developed to inspect and repair the cracks of the welded beads of the heat exchanger tubes of nuclear power plants. Eddy current testing detected inner wall cracks in heat exchanger tubes. The tube thickness was $4.5 \mathrm{~mm}$ and the inner diameter was $23 \mathrm{~mm}$. The minimum detectable depth of the cracks was $10 \%$ of the tube thickness. Endoscope observation confirmed the cracks along the welded beads. Laser welding by a $300 \mathrm{~W}$ compact fiber laser successfully repaired them. The probing system will operate in new nuclear power plants with various laser monitoring technologies for coolant pipes.
\end{abstract}

Key Words: Laser welding, Fiber laser, Heat exchanger, Maintenance, Nuclear power plant

1. はじめに

レーザー技術は原子炉や使用済み燃料の再処理工場の 保守保全に応用可能である. Fig. 1にレーザー応用分野 の分類を示す。この図では, レーザー集光強度とレー ザーパルス幅の関係と, これらに含まれる各種の応用分 野を表している。集光強度が $10^{13} \mathrm{~W} / \mathrm{cm}^{2}$ を超える領域は 超高出力レーザーによる高強度物理の領域である ${ }^{1)}$. フェムト秒からピコ秒にかけての超短パルスレーザー加

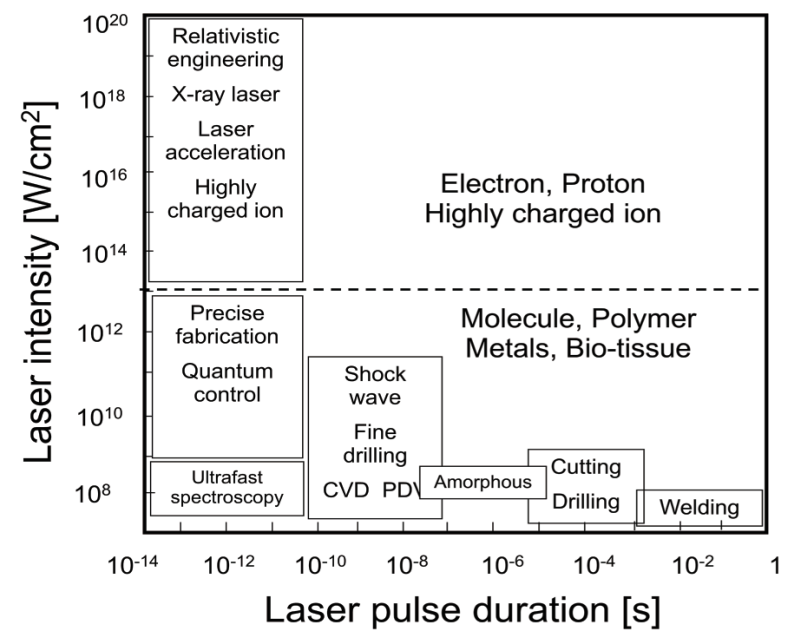

Fig. 1 Laser application field map.
工は，超精密加工手段として技術開発が進められてい る ${ }^{2)} .10^{13} \mathrm{~W} / \mathrm{cm}^{2}$ 以下では，材料に与える熱影響の範囲 を限定できるため, 照射領域周囲の熱影響を最小限度に 抑えることができる。これに続くナノ秒パルスレーザー の領域では，多くの技術開発が進んでいる，特にレー ザーピーニングは, 高経年化軽水炉の応力腐食割れ対策 やタービンブレードの疲労破壊対策として実用化が進ん でいる ${ }^{3)}$. また, 波長変換されたレーザーは, 原子炉の モニタリング装置の光源として活用が進められている. レーザー光の熱作用と非線形効果及び産業用に小型高効 率化されたレーザー装置の利便性を考えると，ナノ秒パ ルスレーザーはこれまで最も実用化が進んでいる。一 方, レーザーパルス幅がマイクロ秒から連続発振の領域 では, 溶接部分の応力改善方法として既に実用化されて いる4)，今後は，表面污染の除去や使用済み燃料集合体 の切断がなされる。この分野の発展は, 特に高出力ファ イバレーザーの開発とロボットアーム及び切断する構造 材の形状と距離の遠隔測定技術らのシステム化が重要で ある。

原子力以外であれば速やかに導入が施行される新技術 も，原子力の分野とりわけ高速増殖炉の分野では，慎重 に着実に進められている，例えば，微量分析技術の高速 増殖炉への応用例として，漏洩したナトリウムの分光分 析が検討されている ${ }^{5),+1}$ 。ここでは，大気圧プラズマ中

\footnotetext{
${ }^{\dagger 1}$ URL: http://www.jsm.or.jp/ejam/OT/jp2/C2.html
} 
で励起準位に励起したナトリウム原子をレーザーイオン 化させ検出している。 また, 大気中のエアロゾルを高度 に濃縮するエアロダイナミックレンズと紫外線パルス レーザー及び電界イオン化を組み合わせた極微量ナトリ

ウム漏洩検出装置が開発された ${ }^{6, \dagger 2}$.

レーザー加工技術はロボット技術に組み込まれて，実 用に供することが出来る新技術に生まれ変わる。特に水 中でのレーザー加工として, 高経年化する軽水炉の保守 保全のため，レーザーピーニングやレーザー溶接及び レーザー超音波探傷が可能な多機能レーザー加工ヘッド が開発されている77. 水中でのレーザー加工は, 炉心よ り水抜きを必要としないことから保守保全時間の短縮が 可能である。 また，水による放射線遮蔽の効果が期待さ れることから, 作業員や精密機器の被爆量低減に効果的 である。

しかしながら，レーザー技術の原子炉保守保全分野に 関しては依然として未開拓の分野が数多くある。本報告 では，ファイバレーザーの特性を活かして開発した熱交 換器の保守保全のための検査補修用プローブについて述 べる. 加えて, 熱交換器配管の溶接部分の監視技術とし て有用な冷却配管のモニタリング技術について述べる。

\section{2. 伝熱管レーザー溶接補修}

原子炉における熱交換器は保守保全の上で重要な機器 である，特に伝熱管の溶接部分は，冷却水による腐食と 流れにより繰り返される振動による疲労破壊に曝されて いる．原子炉鋼材にはクロム鋼が多用される。一般にク ロム濃度を上げれば耐食性が向上するが，割れ感受性が 増大する. 溶接部分は組織の変性が起こり残留応力によ り割れ感受性も高まっている場合も多い. とりわけ炭素 含有量が高いクロム鋼の場合, 溶融凝固により結晶粒界 に沿ってクロム炭化物が生成すると, この生成部分に 沿ってクロムの久乏層が生じるため，腐食割れが進展す ることが知られている. また, 熱交換器の内部の冷却水 の流れは, 伝熱管のサポート部分などで渦を発生し, 繰 り返しの振動を溶接部分に加えることになる。軽水炉の 熱交換器においては，伝熱管の内外は水であるが高速炉 の場合, 伝熱管の外側は金属ナトリウムであり内側は水 である.このため, 水側からナトリウムへの漏洩は高温 の腐食性反応生成物の噴流となり, 周囲の伝熱管にも被 害が拡大する。このため, 伝熱管においては割れの初期

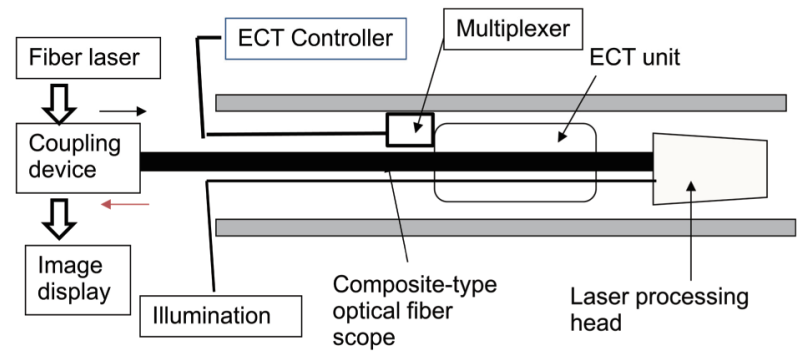

Fig. 2 Schematic view of the probing system.
段階での発見がきわめて重要である.

\section{1 伝熱管内壁検査補修用プローブの概要}

新型プローブは内径の熱交換器伝熱管の内部に挿入 し，伝熱管内壁の欠陥を検査補修することが出来る機能 をもつ．現在の原子炉の保守保全の考え方は検査に重点 が置かれ，欠陥が発見された伝熱管は施栓を行い使用中 止とするのが基本方針である。この新型プローブは検査 機能を強化するために，ファイバスコープと渦電流探傷 機能を一体化し, 渦電流探傷による高速検査とファイバ スコープによる目視確認を両方についてプローブを入れ 替えることなく実施できる.

目視観察により確認された伝熱管内壁の割れはレー ザー照射により溶接補修を行う。使用された伝熱管の内 壁は高温水中で酸化され黒色のマグネタイトにより覆わ れた状態となる。 Fig. 2に新型プローブの概要を表す. プローブの中心軸に複合型光ファイバを配した。この複 合型光ファイバスコープは, 溶接のための高出力レー ザー光とレーザー照射部分の映像を双方向に伝送でき る.この複合型光ファイバが最初に使用されたのは, 国 際熱核融合実験炉 (International Thermonuclear Experimental Reactor)のトリチウム増殖ブランケットの保守保全装置 である ${ }^{8)}$. 当時開発された装置は, $1 \mathrm{~kW}$ の YAGレーザー 光を伝送し，ブランケットに敷設された冷却配管を内部 より切断することを目標とした。

\section{2 レーザー溶接補修のためのファイバスコープ}

現在では複合型光ファイバは，内視鏡外科手術におけ る施術失敗のリスクをできるだけ低減するために，その 特性を活かして臨床応用機器として開発も進められてい る. 消化器系, 脳外科, 脺臓, 胎児外科などの医療応用 について臨床応用を進めている ${ }^{9)}$ 。この複合型光ファイ バの特性は，常に観察している視野の中心にレーザーが 照射されるという点にある，操作する際には，観察像の 円周部分に照射部分を捉え, その照射部分と中心のコア ファイバ部分を重ねることで，対象に確実にレーザーの 照射が可能である，複合型光ファイバの構造とレーザー 加工ヘッドについての詳細は別報を参照されたい ${ }^{10)}$.

Fig. 3 (a) は複合型光ファイバの鏡筒部分の正面を示 す。コアファイバはレーザー溶接のための $1070 \mathrm{~nm} の$ 波 長のレーザー光とアライメントのための630 nmの波長

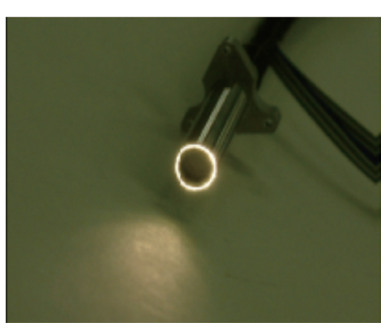

(a)

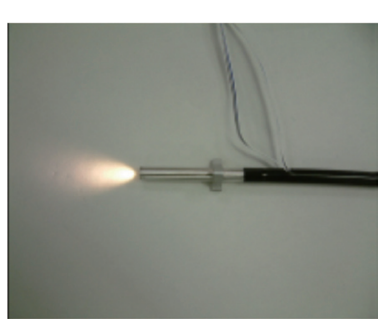

(b)
Fig. 3 Composite-type optical fiber scope. (a) Telescope section, (b) side view.

${ }^{\dagger 2}$ URL: http://jolisfukyu.tokai-sc.jaea.go.jp/fukyu/mirai-en/2009/index_set.html 
の半導体レーザー光が透過する。このため望遠鏡の鏡筒 内部には集光レンズが組み込まれている. 集光レンズ は，4枚構成の石英レンズであり，光ファイバの端部の 像を伝熱管内壁の表面に転送する。開発した複合型光 ファイバの全長は $10 \mathrm{~m}$ であり，3層の構造から構成され る。中心となるコアファイバは $0.2 \mathrm{~mm}$ 直径であり，溶 接補修のための高エネルギーレーザー光を伝送する。 レーザー光の波長は1070 nmである. 映像伝送用の光 ファイバはレーザー伝送用のコアファイバを同心円状に 取り巻いている。伝送される映像は20000本の画素より 構成され, 複合型光ファイバの端面から鏡筒内の4枚構 成の石英レンズによりCCDカメラに像転送される。3層 目は照明のためのライトガイドである. Fig. 3 (b) は鏡 筒部分の側面部分を表す. Fig. 3 (a)，（b)はライトガイ ドにキセノンランプを接続し, 鏡筒部分から照らした様 子を示す.

Fig.4は複合型光ファイバを使用した新型プローブシ ステムの外観である. 全長が70 cmのプローブは渦電流 探傷Eddy Current Testing (ECT) 部分が中空構造となって おり, この中空部分に複合型光ファイバを通し，その端 部にレーザー加工ヘッドが接続される. ECT部分は中空 コイルとマルチプレクサの回路基板より構成される.

近年, ファイバレーザーは高出力化, 小型化, 高安定 性，価格低下が進んでいる。レーザー溶接においては， ファイバレーザーを用いて以前の電子ビーム溶接に匹敵 する溶け込み深さが得られている。これはイッテルビウ ムドープ光ファイバと半導体レーザー励起技術の結合に より得られた。特に, シングルモードファイバレーザー により集光スポット径を小さく保つことで，溶接ビード 幅を狭く保ちつつ，熱伝導率の良い銅やアルミニウムの 切断や穿孔や溶接が高速で可能となっている. 本システ ムでは空冷 $300 \mathrm{~W}$ のシングルモードのイッテルビウム ファイバレーザー(IPG Photonics社製)を熱源として使用 した。

レーザー加工ヘッドは, ヘッド内部に可動スリーブを 持ち, 複合型光ファイバスコープからのレーザー光を伝 熱管内壁に導く、レーザー加工ヘッドの主要部品はチタ ン合金を使用した。伝熱管内壁へのレーザー照射位置 は, $360^{\circ}$ 全周と軸方向に $5 \mathrm{~mm}$ の範囲でスキャンするこ とができる。軸方向に $5 \mathrm{~mm}$ 以上移動させる場合は釣り 下げている複合型光ファイバ自体を移動させる。操作者 は2個の独立したパルスモーターを内壁の映像を観察し ながら，マニュアルでスキャン制御する。可動スリーブ 内部には，レーザー波長と可視波長の双方で反射率をも つ耐熱ミラーを設けた。この耐熱ミラーは，銅製のミ ラーベースにベースコートを施し，その上にレーザー波

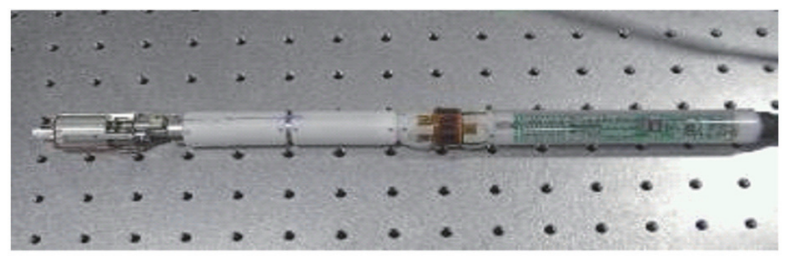

Fig. 4 New probing system.
長に対する誘電体多層膜をコートした。レーザー入射角 は55とした。これによりレーザー光は伝熱管に対して 20 の角度をもって照射される.

\section{3. 熱交換器伝熱管の欠陥検出}

高速炉は軽水炉よりも高温で運転される。もんじゅの 熱交換器は蒸発器と過熱器が直列した構造となってい る。過熱器内は蒸気が流れるが, 蒸発器は水と蒸気の2 相流が流れる。蒸発器は応力腐食割れを避けるためステ ンレス鋼を用いず，2.25\%クロム含有の低クロム鋼が使 用されている。当然, 腐食減肉が進行するため管の肉厚 は十分にとられている。 かつて短期間であるが40\%出力 運転に到達したもんじゅの熱交換器伝熱管は入念なECT 検査が為された。その結果，伝熱管内壁には問題となる 欠陥は発見されず，黒色のマグネタイトの付着が観察さ れたとの報告が為された ${ }^{11)}$.

今後, $40 \%$ を超える出力運転が開始されると, 再び伝 熱管内壁の酸化が進行する。熱交換器はヘリカル構造と なっており，伝熱管に対して垂直にナトリウムの流れが ぶつかることになる。このへリカル構造はナトリウムの 流れに伝熱管が並行して置かれる直管構造と異なり，全 体として熱膨張による伸びと流れによる振動を吸収でき る優れた構造である。その一方で，伝熱管の振動を抑制 するサポートと伝熱管の接触による損傷が予想される.

また，特に構造的に弱い部分は直管とエルボ部分の溶接

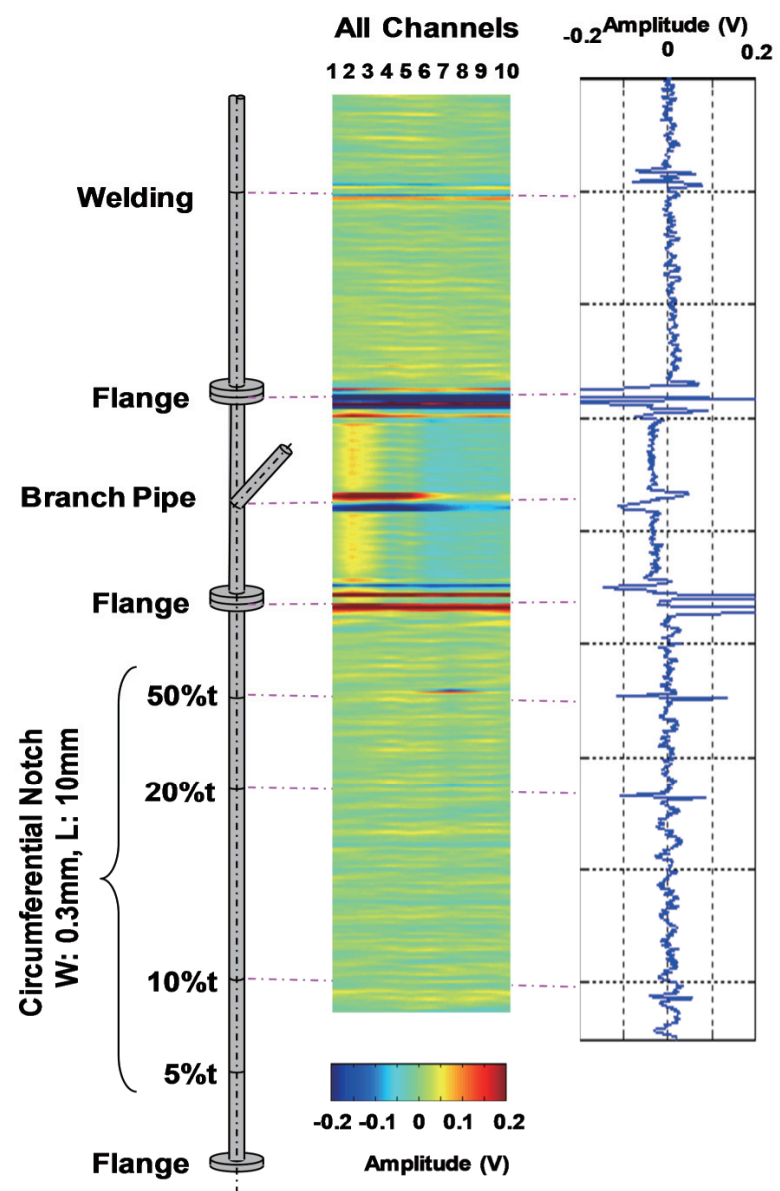

Fig. 5 ECT test for the heat exchanger tube. 
接合部分と考えられる. 現在, もんじゅの4倍以上の出 力の第4世代ナトリウム冷却炉JSFRの要素技術開発が FaCTプロジェクトとして推進されている。 この大型熱 交換器は直管式が候補である ${ }^{12}$.

Fig. 5に渦電流探傷結果の一例を示す。もんじゅの熱 交換器を模擬した試験設備に直管の模擬伝熱管を接続し た後，Fig.4に示したプローブを上部から挿入し， ECT 測定試験を実施した。模擬伝熱管の長さは $1 \mathrm{~m}$, 内径 $23 \mathrm{~mm}$, 厚み $4.5 \mathrm{~mm}$ あ゙る. Fig. 5の図中の左は配管と 模擬伝熱管の接続をイラストで表し, 中央部にはECTの 探傷コイル10チャンネル分の信号を表している. 図の右 には一例としてチャンネル7からのECT信号の振幅を表 した。フランジ部分では全チャンネルから強い信号が検 出されている．枝管部分は分岐している方向に強い信号 が現れる，次に強い信号は直管同士の突き合わせ溶接部 分である.これらの信号に比べて, 模擬伝熱管の内壁に 周方向に放電加工で設けたノッチからの信号は微弱であ る。ノッチの幅は $0.3 \mathrm{~mm}$, 長さは $10 \mathrm{~mm}$ である。 ノッチ の深さは管の厚み $4.5 \mathrm{~mm}$ に対して，その50\%，20\%， 10\%，5\%の4種類である．ECT信号をロックインアンプ により検波増幅し, 数值フィルタによりノイズ除去を施 すことで，ノッチ深さ10\%の欠陥ならば検出することが 可能である.

\section{4. レーザー溶接による欠陥補修}

酸化膜で覆われた伝熱管内壁の反射率は低い.このた め, レーザー光が伝熱管内壁に照射されると, 有効に吸 収される. Fig. 6 (a) は熱交換器伝熱管内壁の欠陥の形 状の様子である。映像中心部のコアファイバを欠陥の形 状に沿ってトレースさせる。欠陥の平均幅は約 $1.2 \mathrm{~mm}$ であり，コアファイバの直径は $0.2 \mathrm{~mm}$ と同程度であ る。倍率は6倍であり, Fig. 6 (a) に示す視野は伝熱管内 壁上で $4.8 \mathrm{~mm}$ である。この実験では, 光ファイバから のパワー密度は約 $1 / 36$ となって欠陥部分に照射される。

Fig. 6 (b) は, レーザー出力50 Wの際のレーザー照射面 の映像である，照射面は融点に達している，伝熱管内に はレーザー照射部から多量のヒュームが発生する。この ヒューム抑制のために，管内をアルゴンガスで満たすと ともに、レーザー加工ヘッドなどの光学系を保護のため アルゴンガスの流れを設ける。

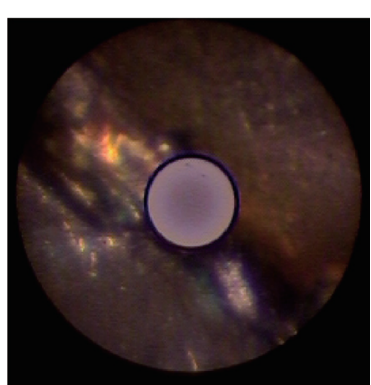

(a)

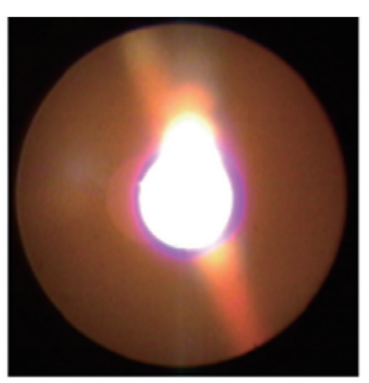

(b)
Fig. 6 Fiberscope views of the heat exchanger tube (a) the crack on the inner wall, (b) laser welding to the crack.
Fig. 7 (a)〜 (d) にレーザー溶接補修試験結果の一例を 示す。レーザー出力は $330 \mathrm{~W}$, スキャン速度は $1.43 \mathrm{~mm} / \mathrm{s}$ で実施した。溶接補修は突き合わせ部分の内壁に対し て，円周方向に $70^{\circ}$ の角度にわたり行った。レーザー照 射時間は10秒である. Fig. 7 (a)では, コアファイバを 中心として左斜め上方向に突き合わせ部分が観察され る。コアファイバから左斜め下方向は溶接ビードであ る. Fig. 7 (b) 及びFig. 7 (c) では1.5 mm幅の溶接ビード が明瞭に観察できる. Fig. 7 (d) ではレーザー溶接の終 端部分であり， $2 \mathrm{~mm}$ 直径の溶融池が形成されている. レーザー溶接の深さ方向の知見は試料切断面の観察によ り得られる。ささに, 溶融池の深さ方向の進展は, 放射 光を用いたX線吸収コントラスト撮影により解明を進め ている ${ }^{13)}$.

\section{5.レーザー利用による配管モニタリング技術}

前章で述ベたレーザー溶接技術は原子炬の補修技術で ある，補修に先立って必要となる技術は原子炉のモ二夕 リング技術である。現在, 超短パルスレーザー加工 ${ }^{14)}$ 活用したFiber Bragg Grating (FBG)の作製技術の開発を 進めている。これはフェムト秒領域の超短パルスレー ザー光を顕微鏡に導き, 通信用光ファイバのコア部分に 集光し，高屈折率のドットを形成する技術である。コア 部分に沿って規則的に並んだドット列は回折格子として 機能し，特定の波長の光を反射する ${ }^{15)}$. 波長1530 $1580 \mathrm{~nm}$ 範囲内に複数の反射ピークをもつFBGセンサの 試作に成功した ${ }^{16)}$ ，反射波長の異なる多数のセンサを一 本の光ファイバに設けることに成功した，紫外線干渉露 光により作製されている沉用FBGセンサは原子炉のよう な高温では使用できないが，フェムト秒レーザー加工に より作成したFBG構造は十分な耐性を有する。従ってこ のセンサを複雑な配管に沿わせて設置することで原子炉 のようなプラントの状態監視が可能となる ${ }^{17)}$.

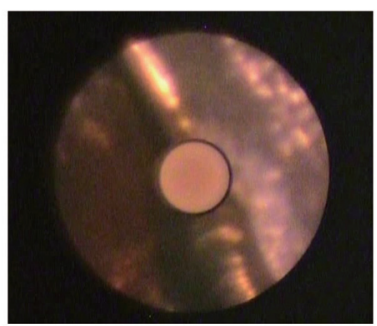

(a) starting position

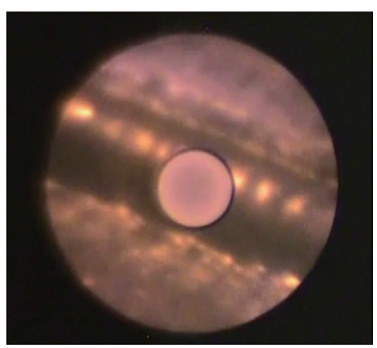

(c) 46 degree position

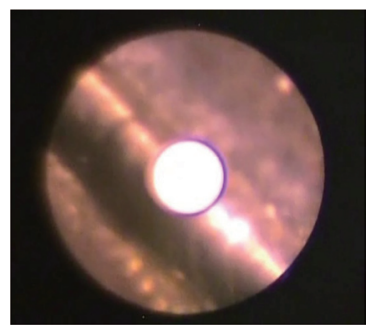

(b) 23 degree position

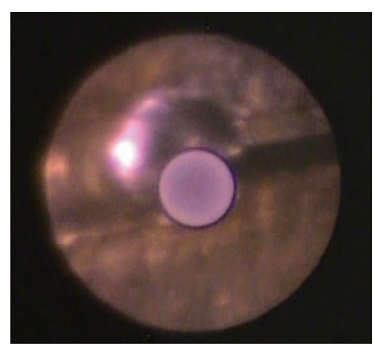

(d) end position
Fig. 7 Endoscope view of laser welding bead. 
原子炉の状態監視の必要性は地震のような予測できな い大きな外力が加わる時だけではない，通常の運転にお いても重要である。特に起動時や停止時など，原子炉の 冷却配管は立ち上げや緊急停止の際の温度変化による膨 張や収縮が繰り返されると, 溶接部分の強度が低下す る.ささら地震により大きな外力が加わると破断の危険 性が増す。とりわけ高速炉のような低圧且つ高温で運転 される原子炉は，冷却配管の厚みが軽水炉よりも薄いた め, 振動や変形の状態監視は一層念入りに行う必要があ る.

レーザー技術の有用性は対象との距離が確保できる点 にある，特に原子力分野では, 高温, 放射線, 機器設計 の上での狭险な構造などの要因から，遠隔且つ非接触の 計測が必要となる場合が多い。これについては実際の事 故例が良い教訓となろう。1995年12月8日，もんじゅの2 次系冷却配管Cループにおいて, 熱伝対鞘管の振動疲労 破損箇所よりナトリウム漏れが生じた。 もんじゅには液 体金属ナトリウムに対して通電検知で反応する漏洩セン サが多数設けられていたが，実際に動作したのは煙感知 器であり，金属ナトリウムが酸化しエアロゾルとなり室 内に充満した。現在の原型炉もんじゅで使用されている 漏洩ナトリウム検出法は, 依然として通電検知による漏 洩センサとエアロゾル吸引法である。エアロゾル吸引法 は，濾紙の上に吸引されたエアロゾルに対して $\mathrm{pH}$ 指示 薬を滴下し塩基性を示すことでナトリウム漏洩の有無を 判定するため, 迅速性に問題がある。通電検知の漏洩セ ンサは, 設置不良の問題もあり多くの誤動作に悩まされ た。迅速性と再現性から考えて，レーザー技術によるナ トリウム漏洩モニタリングが望まれる。

\section{6. おわりに}

高速炉の熱交換器伝熱管を対象に，レーザー溶接によ る検査補修用プローブシステムの開発とその性能につい て述べた，短パルスレーザーの特性を活かした種々のセ ンサ製作や構造モニタリング技術などを併用すること
で，原子炉の安全性の向上を行うことが出来る．現在， 3月11日の東日本大震災と福島原発事故により，原子力 発電の信頼性が失われている，各種のレーザー技術によ り原子炉の安全性向上を計ることが喫緊の課題である.

\section{謝 辞}

新型プローブの開発については, 日本原子力研究開発 機構の岡 潔氏が複合型光ファイバとレーザー加工ヘッ ドの開発を担当し, 山口智彦氏はECT関連機器の開発 を担当した。また，エーテックの赤津朋宏氏及び 竹仲佑介氏は技術スタッフとして協力した。 各位に深 く感謝いたします。この開発においては平成19年から 21 年にかけて文部科学省原子力システム研究開発事業から の支援を受けた。関係者に深く感謝いたします。

\section{参考文献}

1) J. Nees, et al.: IEEE J. Sel. Top. Quantum. Electron. 4 (1998) 376.

2) S. Nolte, et al.: J. Opt. Am. B 14 (1997) 2716.

3) Y. Sano, et al.: Nucl. Instr. Meth. B 121 (1997) 432.

4) 浅妻 祐亮 : 保全学 10 (2011) 98.

5) S. Ogura, et al.: JSM 7th Annual Conference at Omaezaki, Shizuoka (2010) Aug. 17, C-2-8.

6) T. Aoyama, et al.: 2008, JAEA R\&D Review, 14-7.

7) 河野 渉, 他：日本保全学会第5回学術講演会 (2007年7月) 要旨集

8) K. Oka, M. Nakahira, K. Taguchi, A. Itoh, and K. Obara: J. Robotics and Mechatoronics 10 (1998) 110.

9) 岡 潔, 関健史, 西村昭彦: 応用物理 80 (2011) No.12.

10）岡 潔, 西村 昭彦, 関 健史, 赤津 朋宏, 山下卓哉：保全 学 8 (2010) 37.

11) K. Takahashi, et al.: 2008 Fall Meeting of the Atomic Energy Society of Japan, Kouchi (2008) B42.

12）日本原子力研究開発機構：第1回FaCT評価委員会, 資料1-2, Nov. 2010.

13) T. Yamada, et al: Digest of the 12th International Symposium on Laser Precision Microfabrication (2011) p.83.

14) 杉岡 幸次：レーザー加工学会誌 16 (2009) 124 .

15) Y. Kondo, et al.: Opt. Lett. 24 (1999) 646.

16) Y. Shimada, A. Nishimura, et al.: JLMN 5 (2010) 99.

17) T. Kobayashi, et al.: 18th Int. Conf. on Optical Fiber Sensors OFS-18, Cancun, Mexico (2006) TuE-12. 